\title{
Basil (Ocimum basilicum L.) a Source of Valuable Phytonutrients
}

\section{Snežana Filip}

Department of Biotechnology and Pharmaceutical Engineering, Faculty of Technology, University of Novi Sad, Bulevar Cara Lazara 1, 21000 Novi Sad, Serbia

\begin{abstract}
Phenolic compounds may be useful in food processing due to their high antioxidative activities and abundance in the plant kingdom. They are of particular interest for applications in the areas of functional foods and nutraceuticals because they act as preserving agents to protect the human body system against degenerative diseases caused by oxidative damage. Among the aromatic and medicinal plants available to the food industry, basil (Ocimum basilicum L.) has promising benefitial properties. This review summarizes our knowledge of available phytonutrients from Ocimum basilicum, antioxidant activity and their health-benefits in prevention of some modern diseases.
\end{abstract}

\section{Introduction}

In the last three decades, espacially in the developed countries of America and Europa, scientists expressed great interest in plant research. Today, abouth $60 \%$ of world population in treatment relies on herbs and natural products that are recognized as an important source of bioactive compounds.

Plants provide abudant bioactive compounds which have many proved health-promoting activities like antioxidant, antimicrobial, antiviral, antihypertensive, antiinflamatory and etc. Polyphenols, as biologically active compounds are applied for preparation of dietary supplements, nutraceuticals, functional food ingredients or cosmeceuticals [1]. Functional foods are those foods or ingredients that when consumed regularly produce a specific beneficial health effect beyond their basic nutritional properties. Normally, these foods contain different amounts and types of bioactive compounds. When a bioactive compound is included in food formulation, with a specific purpose, the new product could be considered a functional food. Health benefits of the new functional food, for example are: decrease in cholesterol levels, alleviation of lactose $/ g l u t e n$ intolerance, faster relief from diarrhea and inhibition of cancer cell proliferation. On the other hand, nutraceuticals, according to definition, are dietary supplements that deliver in a concentrate form of bioactive compounds from food, present in nonfood matrix, and are used with purpose to enhance health in dosage that exceed those that could be obtained from normal foods. They are usually products consumed as pills, tablets, capsules and powder. Nutraceuticals from various sources such as fruits and vegetables, plants, fungi, algae and microalgae have been shown to posses a wide range of biological active compounds (constituents) such as, polyphenols, carotenoids, coumarins, anthhocyanins and others.

Polyphenols are secondary plant metabolites that have a variety of structures and functions in the plants and are well known as antioxidants in the human diet [2]. Antioxidants are vital substances which possess the ability to protect the cells membrane from damage caused by free radical induced oxidative stress [3]. There is an increasing interest in natural antioxidants, e.g., polyphenols, present in medicinal and aromatic herbs, which might help prevent oxidative damage [4]. Polyphenols possess ideal structural chemistry for free radical scavenging activity, and they have been shown to be more effective antioxidants in vitro than tocopherols and ascorbate. Antioxidant properties of polyphenols arise from their high reactivity as hydrogen or electron donors, and from the ability of the polyphenol

\section{Publication History:}

Received: March 15, 2017

Accepted: May 29, 2017

Published: May 31, 2017

\section{Keywords:}

Basil, phytonutrients, Polyphenols, Antioxidant activity derived radical to stabilise and delocalise the unpaired electron (chainbreaking function), and from their ability to chelate transition metal ions [2]. Human body has multiple mechanisms especially enzymatic and non enzymatic antioxidant systems to protect the cellular molecules against reactive oxygen species (ROS) induced damage. However, certain amounts of exogenous antioxidants are constantly required to maintain an adequate level of antioxidants in order to balance the ROS in human body. Many synthetic antioxidants such as butylated hydroxyl anisole (BHA) and butylated hydroxyl toluene (BHT) are very effective and are used for industrial processing. Their used have been restricted because they possess toxic, mutagenic and carcinogenic properties to human health [5]. Hence, compounds especially from natural sources are capable of protecting against ROS mediated damage, they may have potential application in prevention and/or curing of diseases. The phenolic compounds in herbs act as antioxidants due to their redox properties, allowing them to act as reducing agents, hydrogen donors, free radical quenchers and metal chelators [6].

In many cases, plants, mixtures of plants or even extracted compounds are added to the food, in order to provide their beneficial properties [7]. Among the aromatic and medicinal plants available to the food industry, basil has promising beneficial effects.

Basil (Ocimum basilicum L.) belongs to Lamiaceae family, highly aromatic with pleasant taste used mostly in culinary. It is native to Asia, Africa, Central and South America but widely cultivated in many countries, especially in Mediterranean region. It is a green herb that can reach about $90 \mathrm{~cm}$ of height, displaying lanceolate leaves, which are glossy and fragrant. Basil is known for its considerable genetic diversity with between 50 and 150 species reported, based on variation in morphological characteristic such as growing habit, leaf and flower color, size and shape, and aromatic composition [8]. For the incredible aroma, basil is also called "king of the herbs".

"Corresponding Author: Snežana Filip, Department of Biotechnology and Pharmaceutical Engineering Faculty of Technology, University of Novi Sad, Bulevar Cara Lazara 1, 21000 Novi Sad, Serbia, Phone: +381 638571488; E-mail: filipsnezana@gmail.com

Citation: Filip S (2017) Basil (Ocimum basilicum L.) a Source of Valuable Phytonutrients. Int J Clin Nutr Diet 3: 118. doi: https://doi.org/10.15344/2456$8171 / 2017 / 118$

Copyright: (c) 2017 Filip. This is an open-access article distributed under the terms of the Creative Commons Attribution License, which permits unrestricted use, distribution, and reproduction in any medium, provided the original author and source are credited. 
One of the most known uses of this herb is as a spice, and ingredient among the Italian and Southeast Asian cuisines. It is often used mix in salads and various sauces, where the most popular being the Italian pesto. Basil is also, one of the most popular culinary herbs in North America which is used fresh or dried. Basil has been used traditionally in folk medicine for the treatment of inflammation of the respiratory and urinary tracts, for caught, asthma, as a carminative, stomachic and antispasmodic [9].

\section{Cultivar and Chemotaxonomic classification}

Most commercial basil cultivars available in the market belong to the species O. basilicum. Darrah [10] classified the O. basilicum cultivars in seven types:

1. tall slender types, which include the sweet basil group;

2. large-leafed, robust types, including "Lettuce Leaf" also called "Italian" basil;

3. dwarf types, which are short and small leafed, such as "Bush" basil;

4. compact types, also described, O. basilicum var. thyrsiflora, commonly called "Thai" basil;

5. purpurescens, the purple-colored basil types with traditional sweet basil flavor;

6. purple types such as "Dark Opal", a possible hybrid between O. basilicum and $\mathrm{O}$. forskolei, which has lobed-leaves, with a sweet basil plus clove-like aroma and

7. citriodorum types, which includes lemon-flavored basils.

The taxonomy of basil is complicated by existence of numerous botanical varieties, cultivar name and chemotypes within the species that may not differ significantly in morphology [11]. The aromatic character of each type of basil is determined by genotype and depends on the major chemical compounds of essential oils (EOs) primarily consisting of monoterpenes and phenylpropanoids [12]. Chemotypes are generally classified on the basis of prevalent compounds or components $>20 \%$. The aroma compounds such as, linalool, eugenol, methylchavicol, methylcinnamate and citral, can be found in chemotypes of basil. These chemotypes are known by names based on geographical origins such as Egyptian, European, Reunion or Tropical basil [11]. The European type, sweet basil, is considered to have the highest quality aroma containing linalool and methylchavicol as the major constituents [9]. The Egyptian basil is similar to the European, but contains a higher percentage of methylchavicol. The Reunion type, from the Comoro Islands, Madagascar, Thailand and Vietnam, is characterized by high concentration of methylchavicol [12] Tropical basil, from Bulgaria, India, Guatemala and Pakistan is rich in methylcinnamate, while basil from Java, Russia and North Africa is rich in eugenol [9].

\section{Bioactive compounds in basil - Chemical constituents}

Due to presence of secondary metabolites such as essential oils, tannins, phenols, flavonoids, anthocyanins and steroids, Ocimum species have been known for their healthful properties for long time and have been used in tradicional folk medicine.

Basil possess high content of magnesium, potassium and iron (Table 1). Magnesium and potassium, as one of the seven essential macrominerals, improving the health of the cardiovascular system

\begin{tabular}{|c|c|}
\hline Nutritive elements & Content \\
\hline Fat & $0,64 \mathrm{~g}$ \\
\hline Protein & $3,15 \mathrm{~g}$ \\
\hline Water & $92,06 \mathrm{~g}$ \\
\hline \multicolumn{2}{|l|}{ Vitamins } \\
\hline Vitamin A & $264 \mu \mathrm{g}$ \\
\hline$\beta$-Carotene & $3142 \mu \mathrm{g}$ \\
\hline Thiamin $\left(\mathrm{B}_{1}\right)$ & $34 \mu \mathrm{g}$ \\
\hline Riboflavin $\left(\mathrm{B}_{2}\right)$ & $76 \mu \mathrm{g}$ \\
\hline Niacin $\left(B_{3}\right)$ & $902 \mu \mathrm{g}$ \\
\hline Panthotenic acid $\left(\mathrm{B}_{5}\right)$ & $209 \mu \mathrm{g}$ \\
\hline Vitamin $\mathrm{B}_{6}$ & $155 \mu \mathrm{g}$ \\
\hline Vitamin $\mathrm{B}_{9}$ & $68 \mu \mathrm{g}$ \\
\hline Choline & $11,4 \mathrm{mg}$ \\
\hline Vitamin C & $18,0 \mathrm{mg}$ \\
\hline Vitamin E & $0,80 \mathrm{mg}$ \\
\hline Vitamin $\mathrm{K}$ & $414,8 \mu \mathrm{g}$ \\
\hline \multicolumn{2}{|l|}{ Minerals } \\
\hline $\mathrm{Ca}$ & $177 \mathrm{mg}$ \\
\hline $\mathrm{Fe}$ & $3,17 \mathrm{mg}$ \\
\hline $\mathrm{Mg}$ & $64 \mathrm{mg}$ \\
\hline $\mathrm{Mn}$ & $1.148 \mathrm{mg}$ \\
\hline $\mathrm{P}$ & $56 \mathrm{mg}$ \\
\hline $\mathrm{K}$ & $295 \mathrm{mg}$ \\
\hline $\mathrm{Na}$ & $4 \mathrm{mg}$ \\
\hline $\mathrm{Zn}$ & $0,81 \mathrm{mg}$ \\
\hline
\end{tabular}

Table 1: Content of nutritive elements in $100 \mathrm{~g}$ of fresh basil.

and the transmission of nerve impulses, also provide protection from a number of chronic diseases. It is digestive stimulant, and is used as diuretic. It is rich in a variety of important nutrients, most notably vitamin $\mathrm{A}$, vitamin $\mathrm{C}$, calcium and phosphorus. It also contains high concentrations of carotenoids like $\beta$-carotene, and these substances are converted to vitamin A within the body. Beta carotene offers even more benefits than vitamin $\mathrm{A}$ alone, and it is known to be a powerful antioxidant.

Basil is a rich source of polyphenols. Polyphenols include many classes of compounds ranging from phenolic acids, simple or complex flavonoids to colored anthocyanins. In term of pharmacological activity, they act against peroxide oxidation.

\section{Essential oil}

Basil is economically important crop for essential oil production. The EO of basil extracted via steam distillation from the leaves and flowering tops are used to flavor foods, dental and oral products, in perfumery and medicines [9]. The worldwide basil EOs production is about $100 \mathrm{t} /$ year. The basil EO content is in range from 0.5 to 1.0 $\%$ for European chemotype, although variations in the EO content across cauntries might be attributed to the varied climat conditions to the regions. A study by Marotti et al., [12] showed that the EO content in herb of 10 Italian basil cultivar ranged from 0.3 to $0.8 \%$. In a large study on 270 basil accession in Germany, oil content varied 
Citation: Filip S (2017) Basil (Ocimum basilicum L.) a Source of Valuable Phytonutrients. Int J Clin Nutr Diet 3: 118. doi: https://doi.org/10.15344/2456$8171 / 2017 / 118$

Page 3 of 5

from trace to $2.65 \%$. A basil from Fiji has EO content only $0.2 \%$ (dominant compounds: linalool $22.3 \%$, methyleugenol $24.7 \%$ and methylcinnamate $23.6 \%$ ). Basil originated from Cuba has a much higher EO content of 1.9-2.5\% (dominant compounds: methylchavicol $66.8 \%, 1,8$-cineole $5.4 \%$ and linalool $5.0 \%$ ), while basil from Burkina Faso has oil content of $0.7-1.8 \%$ (dominant compounds: 1,8-cineole $60.2 \%$, a-terpineol $6.5 \%$ and $\beta$-pinene $5.7 \%$ ) [13].

There is enormous variation in composition of basil EOs. Essential oils derived from $\mathrm{O}$. basilicum have been tradicionally classified into four distinct chemotypes with many subtypes, based of the major components in the oil: linalool-rich, methylchavicol-rich, methylcinnamate-rich and methyleugenol-rich [14]. The oils from different types of basil and different production areas are of distinct flavors and different value in the world market (Table 2). The European basil EO, with linalool and methylchavicol as the main components, is often considered to have the highest quality and the finest aroma. This type of oil is usually used in the cosmetic and perfume industry. Scented basils (cinnamon, licorice and lemon) are used in jellies, honeys, vinegars and baked products. basil cultivar better protect cardiomyocytes agains oxidative stress than green "Genovese" and "Lettuce Leaf" varieties.

\section{Phenolic acids}

Basil conteins high levels of phenolic acids that contribute to its strong antioxidant capacity [24]. The main phenolic acids reported in basil are rosmarinic, caffeic, caftaric and chicoric acids [25-27]. Rosmarinic acid, as prevalent phenolic acid in basil extracts, is important phytochemical, due to their antioxidant and pharmacology properties. It has been found to be potent active substance against human immunodeficiency virus type 1 (HIV-1) [28]. The phenolic acid content depends of basil cultivar, as well as of extracts obtained by different solvents and extraction methods. In the Table 4 are presented total phenolics, flavonoids and anthocyanins from different Ocimum basilicum varieties. Total phenolic content and concentration of phenolic acids in basil is strongly dependent on environmental conditions during growth, including temperature and photoperiod, nutrient availability in soil and seasonal, geographical and climate variation. Also, same commercial basil products may

\begin{tabular}{|l|l|l|l|l|}
\hline \multirow{2}{*}{ Cultivar } & \multicolumn{2}{|c|}{ Color } & Y $(\%, \mathrm{~V} / \mathrm{w})$ & Major compaunds \\
\cline { 2 - 5 } & Leaf & Flower & & \\
\hline Anise & green-purple & light-pink & 0.62 & linalool (56\%), methylchavicol (12\%) \\
\hline Cinnamon & green & pink & 0.94 & linalool (47\%), methylcinnamate (30\%) \\
\hline Dark Opal & purple & pink & 1.08 & linalool (80\%), 1,8-cineole (12\%) \\
\hline Genovese & green & white & 0.90 & linalool (77\%), 1,8-cineole (12\%) \\
\hline Italian Large Leaf & green & white & 0.83 & linalool (65\%), methylchavicol (18\%) \\
\hline Licorice & green-purple & pink & 0.43 & linalool (58\%), methylchavicol (13\%) \\
\hline Mammoth & green & white & 0.77 & linalool (60\%), methylchavicol (32\%) \\
\hline Napoletano & green & white & 0.89 & linalool (66\%), methylchavicol (10\%) \\
\hline Opal & purple & pink & 0.91 & linalool (80\%), 1,8-cineole (13\%) \\
\hline Osmin Purple & purple & pink & 0.66 & linalool (77\%), 1,8-cineole (15\%) \\
\hline Purple Ruffles & purple & $\begin{array}{l}\text { bright } \\
\text { purple }\end{array}$ & 0.49 & $\begin{array}{l}\text { linalool (55\%), 1,8-cineole (20\%), methylchavicol (6\%), } \\
\text { methyleugenol (9\%) }\end{array}$ \\
\hline Red Rubin Purple & purple & pink & 0.74 & $\begin{array}{l}\text { linalool (70\%), 1,8-cineole (9\%), methylchavicol (10\%), } \\
\text { methyleugenol (6\%) }\end{array}$ \\
\hline Sweet & green & white & 0.84 & linalool (69\%), 1,8-cineole (11\%), methylchavicol (13\%) \\
\hline Sweet Fine & green & white & 0.98 & linalool (86\%), 1,8-cineole (6\%) \\
\hline Sweet Thai & green & pink & 0.40 & linalool (6\%), methylchavicol (60\%) \\
\hline Thai (Richters) & green & pink & 0.52 & methylchavicol (90\%) \\
\hline
\end{tabular}

Table 2: Essential oils yield (Y) and chemical compositions of some O. basilicum cultivars [9].

The essential oil of basil have diverse properties. It have been shown antiviral [15], antioxidant [16], antiinflammatory [17], antidiabetic activities [18] and inhibitory activity against HIV-1 [19]. Strong antimicrobial effects on Gram-positive, Gram-negative bacteria, yeast and molds were demostrated [20]. Prasad et al., [21] studied the antimicrobial activity of EO of basil from France, India and Niazbo, which are rich in linalool, methylchavicol and methylcinnamate, respectively, against $11 \mathrm{Gram}$-positive and $7 \mathrm{Gram}$-negative bacteria. They found that these oils were more effective against Gram-positive than against Gram-negative bacteria. Fungistatic effect of basil oils was also observed [21,22]. Essential oil showed insecticidal activity and entire plant, as well as EO, is well known insect repellent [13]. Recent research from Danesi et al., [23], found that EOs from a purple have some phenolic acids degradation due to age, storage conditions, and/or the drying process. The main role of phenolic acids is as antioxidants. The antioxidative activity of phenolic acids is mainly due to their redox properties, which can play an importante role in neutralizing free radicals, quenching singlet and triplet oxygen or decomposing peroxide [24]. Hence, they exhibited other benefites, may be protective against cardiovascular diseases, act as antiplatelet and anti-inflammatory agens. The phenolic content and antioxidantactivity of basils were similar to red and black raspberry and higher than rosehips [29].

\section{Flavonoids and anthocyanins}

Flavonoids are phenolic substances isolated from a wide range of 
plants, which act as antioxidants, antimicrobials, photoreceptors, visual atractors, feeding repellents and for light screening in plants. In human body exhibited different biological activities, including antiallergenic, antiviral, anti-inflammatory and vasodilating actions, and are important components in the human diet. However, most interest has been devoted to the antioxidant activity of flavonoids, which is due to their ability to reduce free radicals. Flavonoids isolated from basil belongs to flavones and flavonols subgroup which occur as glycosylated derivatives. The research performed by Grayer et al., [33] showed that the dominant components in O. basilicum were: quercetin, luteolin, apigenin and kaempferol mainly as O-glycosides.

The intensively purple pigmented basils are good source of anthocyanins. Certain purple basil cultivars have substantial levels of anthocyanins, water-soluble phenolic compounds primarily responsible for red, purple and blue pigmentation in plants. Anthocyanins have diverse functions within the plants, ranging from defensive to protective roles [34] to facilitating growth, development and reproduction [35]. They possess antioxidant properties and radical scavenging abilities that have been correlated with disease prevention in humans. The benefites of their consumption is associated with neuroprotective effects particulary decreased risk of Parkinson's desease [36]. In the Table 5 anthocyanin levels in basil were compared with other plant sources. Acording to Simon et al., [9] fourteen different anthocyanins were identified, mostly cyanidin and peonidin glycosides. Total anthocyanins ranging from 0.07 to $0.19 \mathrm{mg}$ /g of fresh weight. Flanigan \& Niemeyer [30] investigated 8 diferent purple basil varieties, where anthocyanins varied from 7.55 to 16.6 $\mathrm{mg} / \mathrm{g}$ dry weight (DW). From the obtained results, purple basil can be considered as an abundant source of anthocyanins and red pigments valuable for food industry.

\section{Flavonoids and anthocyanins}

New research has shown that the consumption of plant polyphenolics may have protective properties against cardiovascular, neurodegenerative and inflammatory disease, diabetes and certain forms of cancer [37]. Basil is a medicine herb used in traditional medicine, including Ayurveda, particularly for relieving stress and in Chinese medicine to treat cardiovascular disease including hypertension. It is useful anti-inflammatory agent that reduce inflammation abouth 54\%. Amrani et al., [38] demonstrated in vivo anti-platelet aggregation and antithrombotic effects of aqueous basil extracts. New results indicated a significant decrease of blood glucose level and plasma total cholesterol, LDL-cholesterol and triglycerides levels $[39,40,18]$.

According to literature data, cytotoxic activity of O. basilicum EO and extracts were investigated by Zarlaha et al., [41] in vitro, on four different humans cancer cell lines: the human cervix adenocarcinoma HeLa cells, human melanoma FemX cells, human chronic myelogenous leukaemia K562 cells and human ovarian SKOV3 cells. In this study, isoeugenol, eugenol, linalool and caffeic acid exhibited high cytotoxicity and anticancer activity against human ovarian SKOV3 cells. Cytotoxic activity of O. basilicum EO was recognized by Kathirvel \& Ravi [42] against HeLa i HEp-2 tumor cells. The researchers in this field, with various basil extracts, are still continuous.

With so many health benefits basil has become increasingly popular. The extracts and EOs of aromatic/medicinal plants have been considered not only for prevention of treatment of various diseases, but also as a natural food preservatives. In the field of food production, carcinogenicity of some synthetic antioxidants (BHT and BHA) led to the substitution of such antioxidants with safe additives/extracts obtained from natural sources with proven antioxidant capacity. Nowadays, the tendency in food and pharmaceutical industry is to replace synthetic antioxidants with the natural ones. For these reasons, there is a growing interest in analyzing natural, non-toxic and healthy herbal extracts, with antioxidant properties which may be used as additives. As additive and antioxidant, EO of basil was added in beef burger products [43]. The benefits were inhibition of lipid oxidative degradation, which is manifest in no changes of organoleptic properties present as flavor, color and texture. In these product EO acting as antimicrobial agents. Despite all these beneficial effects, a few studies report the incorporation of basil in foodstuffs. Basil and its extracts are used to flavor and preservation olive oils [44]. Such products are highly appreciated by consumers due to their intense color and aromatic characteristics. Direct aromatization of olive oil with basil is a new trend in the Mediterranean area, both for sensory and for nutritional improvement [45]. In Turkey, fresh basil is also consumed with yogurt because of basils positive contributions. Basil leaves were incorporated in Portugal "Serra da Estrela" cheese to test their functional and preservative properties [46], with idea for novel food products with natural ingredient. Basil seeds are well source of polysaccharides [47]. When it is soaked in water, become gelatinous, and is used in Asian drinks and desserts.

\section{Conclusion}

A number of basils have commercial potential for the production of industrial products. For example, camphor-rich or eugenol-rich basil chemotypes can be potential industrial source of natural compounds - camphor/eugenol. Simon et al., [9] concluded that purple basil contain very high concentration of total anthocyanins and are valuble sorces of these components, which may serve as potential new source of red pigments for the food industry. Numerous studies have confirmed the potency of $O$. basilicum as natural antioxidant, due to the prevalence of polyphenolic compounds. Rosmarinic acid, the main active component found in basil, has been proven to have medicinal value, and its superior antioxidant activity with vitamin $\mathrm{E}$. The antioxidant activity of basil EO and extracts was few times higher than reported activity of different herbal essential oils (Lavandula angustifolia, Majorana hortensis, Mentha piperita, Rosmarinus officinalis, Origanum onites) which antioxidant capacity has been recognized as important All in all, for medicinal benefits, intensively consumption of basil, EOs and extracts in food and pharmaceutical industry are of interest.

\section{Competing Interests}

The authors declare that they have no competing interests.

\section{References}

1. Peschel W, Sanchez-Rabaneda F, Diekmann W, Plescher A, Gartzia L, et al. (2006) An industrial approach in the search of natural antioxidants from vegetable and fruit wastes. Food Chem 97: 137-150.

2. Rice-Evans C, Miller N, Paganga G (1997) Antioxidant properties of phenol compounds. Trends Plant Sci 2: 152-159.

3. Rao KS, Chaudhury PK, Paradhan A (2010) Evaluation of antioxidant activities and total phenolic content of Chromolaena odorata. Food Chem Toxicol 48: 729-732.

4. Wojdylo A, Oszmianski J, Czemerys R (2007) Antioxidant activity and phenolic compounds in 32 selected herbs. Food Chem 105: 940-949. 
5. Cooper CS, Grover PL (2012) Chemical carcinogenesis and mutagenesis II. Cooper CS and Grover PL (Eds), Springer-Verlag, Berlin, Heidelberg, pp. 164-170.

6. Javanraedi J, Stushnoff C, Locke E, Vivanco JM (2003) Antioxidant activity and total phenolic content of Iranian Ocimum accessions. Food Chem 83 547-550.

7. Neacsu M, Vaughan N, Raikos V, Multari S, Duncan GJ, et al. (2015) Phytochemical profile of commercially available food plant powders: Thei potential role in healthier food reformulations. Food Chem 179: 159-169.

8. Makri O, Kintzios S (2007) Ocimum sp. (Basil): Botany, cultivation, pharmaceutical properties and biotechnology. J Herbs Spices Med Plants 13: $123-150$

9. Simon JE, Morales MR, Phippen WB, Vieira RF, Hao Z (1999) Basil: A source of aroma compounds and a popular culinary an ornamental herb. In Perspectives on new crops and new uses, Janick J (Ed); ASHS Press: Alexandria , VA, pp 499-505.

10. Darrah HH (1980) The cultivated basil. Buckeye Printing Company Independence, MO.

11. Simon JE, Morales MR, Phippen WB, Vieira RF, Hao Z (1990) Basil: A source of essential oils. Janick $J$ and Simon JE (Eds); Advances in new crops. Timber Press, Portland, OR, 484-489 p.

12. Marotti M, Piccaglia R, Giovannelli E (1996) Differences in essential oil composition of Basil (Ocimum basilicum L.) Italian cultivar related to morphological characteristics. J Agric Food Chem 44: 3926-3929.

13. Keita SM, Vincent C, Schmit JP, Belanger A (2000) Essential oil composition of Ocimum basilicum L., O. gratissimum L. and O. suave L. in the Republic of Guinea. Flavour Fragr J 15: 339-341.

14. Lawrence BM (1988) A World Perspective. Proceedings of the 10th International Congree of Essential Oils, Fragrances and Flavours, Washington, DC, USA 1986, Elsevier Sciences Publisher B.V.: Amsterdam 161.

15. Sanchez E, Garcia S, Heredia N, (2010) Extracts of edible and medicinal plants damage membranes of Vibrio cholerae. Appl Environ Microb 76: 6888-6894.

16. Jayasinghe C, Gotoh N, Aoki T, Wada S (2003) Phenolics composition and antioxidant activity of sweet basil (Ocimum basilicum L.). J Agric Food Chem 51: 4442-4449.

17. Kelm MA, Nair MG, Strasburg GM, DeWit DL (2000) Antioxidant and cyclooxygenase inhibitory phenolic compounds from Ocimum sanctum Linn. Phytomedicine 7: 7-13.

18. Wongsa P, Chaiwarit J, Zamaludien A (2012) In vitro screening of phenolic compounds, potential inhibition against $\alpha$-amylase and $\alpha$-glucosidase of culinary herbs in Thailand. Food Chem 131: 964-971.

19. Yamasaki K, Nakano M, Kawahata T, Mori H, Otake T, et al. (1998) Ant HIV-1 activity of herbs in Labiatae. Biol Pharm Bull 21: 829-833.

20. Hussain Al, Anwar F, Sherazi STH, Przybylski R (2008) Chemical composition, antioxidant and antimicrobial activities of basil (Ocimum basilicum) essential oils depends on seasonal variations. Food Chem 108 986-995.

21. Prasad G, Kumar A, Singh AK, Bhattacharya AK, Singh K, et al. (1986) Antimicrobial activity of essential oils of some Ocimum species and clove oil. Fitoterapia 57: 429-432.

22. Rai MK, Qureshi S, Pandey AK (1999) In vitro susceptibility of opportunistic Fusarium spp. to essential oils. Mycoses 42: 97-101.

23. Denesi F, Elementi S, Neri R, Maranesi M, D`Antuono LF, Bordoni A (2008) Effect of cultivar on the protection of cardiomyocytes from oxidative stress by essential oils and aqueous extracts of basil (Ocimum basilicum L.). J Agric Food Chem 56: 9911-9917.

24. Javanmardi J, Khalighi A, Kashi A, Bais HP,Vivanco JM (2002) Chemical characterization of basil (Ocimum basilicum L.) found in local accessions and use in traditional medicines in Iran. J Agric Food Chem 50: 5878-5883.

25. Lee J, Scagel CF (2009) Chicoric acid found in basil (Ocimum basilicum L.) leaves. Food Chem 115: 650-656

26. Lee $\mathrm{J}$ (2010) Caffeic acid derivatives in dried Lamiaceae and Echinacea purpurea products. J Funct Foods 2: 158-162.

27. Kwee EM, Niemeyer ED (2011) Variations in phenolic compositions and antioxidant properties among 15 basil (Ocimum basilicum L.) cultivars. Food Chem 128: 1044-1050.

Int J Clin Nutr Diet

ISSN: $2456-8171$
28. Mazumder A, Neamati N, Sunder S, Schulz J, Pertz H, et al. (1997) Curcumin analogues with altered potencies against HIV-1 integrase as probes for biochemical mechanisms of drug action. J Med Chem 40: 30573063.

29. Juliani HR, Simon .E (2002) Antioxidant activity of Basil. Trends in new crops and new uses. Janick $J$ and Whipkey A (eds.), ASHS Press, Alexandria, VA, pp. 575-579.

30. Flanigan PM, Niemeyer ED (2014) Effect of cultivar on phenolic level, anthocyanin composition and antioxidant properties in purple basil (Ocimum basilicum L.). Food Chem 164: 518-526.

31. Izadiyan P, Hemmateenejad B (2016) Multi-response optimization of factors affecting ultrasonic assisted extraction from Iranian basil using central composite design. Food Chem 190: 864-890.

32. Koca N, Karaman S (2015) The effects of plant growth regulators and I-phenylalanin on phenolic compounds of sweet basil. Food Chem166: 515-521.

33. Grayer RJ, Kite GC, Veitch NC, Eckert MR, Marin PD, et al. (2002) Leaf flavonoid glycosides as chemosystematic characters in Ocimum. Biochem Syst Ecol 30: 327-342.

34. Gould KS (2004) Nature`s Swiss army knife: The diverse protective roles of anthocyanins in leaves. J Biomed Biotechnol 5: 314-320.

35. Holton TA, Cornishe EC (1995) Genetics and biochemistry of anthocyanins biosyntesis. The Plant Cell : 1071-1083.

36. Gao X, Cassidy A, Schwarzchild MA, Rimm EB, Ascherio A (2012) Habitual intake of dietary flavonoids and risk of Parkinson`s disease. Neurology 78 $1138-1145$

37. Gross M (2004) Flavonoids and cardiovascular disease. Pharm Biol 42 21-35.

38. Amrani S, Harnafi H, Gadi D, Mekhfi H, Legssyer A, et al. (2009) Vasorelaxant and anti-platelet aggregation effects of aqueous Ocimum basilicum extract. J Ethnopharmacol 125: 157-162.

39. Amrani S, Harnafi $\mathrm{H}$, Bouanani $\mathrm{NH}$, Aziz M, Serghini-Caid $\mathrm{H}$, Manfredini S Besco E, Napolitano M, Bravo E (2006) Hypolipidemic activity of aqueous Ocimum basilicum extract in acute hyperlipidaemia induced by triton WR 1339 in rats and its antioxidant property. Phytother Res 20: 1040-1045.

40. Zeggwagh NA, Sulpice T, Eddouks M (2007) Anti-hyperglycaemic and hypolipidemic effects of Ocimum basilicum aqueous extract in diabetic rats. Amer J Pharm Toxic 2: 123-129.

41. Zarlaha A, Kourkoumelis N, Stanojković TP, Kovala-Demertzi D (2014) Citotoxic activity of essential oil and extracts of Ocimum basilicum against human carcinoma cells. Molecular docking study of isoeugenol as a potent cox and lox inhibitor. Dig J Nanomater Biostruct 9: 907-917.

42. Kathirvel P, Ravi S (2012) Chemical composition of the essential oil from basil (Ocimum basilicum Lnn.) and its in vitro citotoxicity against HeLa and Hep-2 human cancer cell lines and NIH 3T3 mouse embrionic fibroblasts. Nat Prod Res 26: 1112-1118.

43. Sharafati-Chaleshtori R, Rokni N, Rafieian-Kopaei M, Drees F, Salehi E (2015) Antioxidant and antibacterial activity of basil (Ocimum basilicum L.) essential oil in beef burger. J Agr Sci Tech 17: 817-826.

44. Perez RA, Navarro T, De Lorenzo C (2007) HS-SPME analysis of the volatile compounds from spices as source of flavour in "Campo Real" table olive preparations. Flavour Fragr J 22: 265-273.

45. Veillet S, Tomao V, Chemat F (2010) Utrasound assisted maceration: An original procedure for direct aromatisation of olive oil with basil. Food Chem 123: $905-911$.

46. Carocho M, Barros L, Barreira JCM, Calhelha RC, Soković M, et al. (2016) Basil as functional and preserving ingredient in Serra da Estrela" cheese. Food Chem 207: 51-59.

47. Razavi SMA, Mortazavi SA, Matia-Merino L, Hosseini Parvar S Motamedzadegan A, et al. (2009) Optimisation study of gum extraction from Basil seed (Ocimum basilicum L.). Int J Food Sci Tech 44: 1755-1762. 